\title{
Performance of a Novel Decentralised Sewage Treatment Reactor
}

\author{
Dong Sheng Shen, ${ }^{1,2}$ Bao Cheng Huang, ${ }^{1,2}$ Hua Jun Feng, ${ }^{1,2}$ Bo Zhao, ${ }^{1}$ Jiang Ming Zhao, ${ }^{1}$ \\ Hai Yang Zhang, ${ }^{3}$ and Pei-Qing $\mathrm{Liu}^{4}$ \\ ${ }^{1}$ College of Environmental Science and Engineering, Zhejiang Gongshang University, Hangzhou, Zhejiang 310018, China \\ ${ }^{2}$ Zhejiang Provincial Key Laboratory of Solid Waste Treatment and Recycling, Zhejiang Gongshang University, \\ Hangzhou Zhejiang 310018, China \\ ${ }^{3}$ Suzhou Industrial Technology Research Institute of Zhejiang University, Suzhou, Jiangsu 215163, China \\ ${ }^{4}$ China SINOMACH Heavy Industry Corporation, 16 Shunbei Road, Beijing 100102, China \\ Correspondence should be addressed to Hua Jun Feng; fenghuajun@mail.zjgsu.edu.cn
}

Received 19 April 2013; Accepted 27 July 2013

Academic Editor: Athanasios Katsoyiannis

Copyright $\odot 2013$ Dong Sheng Shen et al. This is an open access article distributed under the Creative Commons Attribution License, which permits unrestricted use, distribution, and reproduction in any medium, provided the original work is properly cited.

A novel decentralised sewage treatment reactor (DSTR) for treating domestic sewage in rural areas was designed and investigated. The reactor was started aerobically after inoculation with biomass; the amount of initial mixed liquid suspended solids was $1.5 \mathrm{~g} / \mathrm{L}$. Oxygen was supplied to the reactor and the dissolved oxygen concentration was maintained at $1.3 \pm 0.2 \mathrm{mg} / \mathrm{L}$. The pollutant removal performance was investigated, and the average removal efficiencies of total chemical oxygen demand (TCOD), $\mathrm{NH}_{4}{ }^{+}-\mathrm{N}$, suspended solids, and turbidity were $76 \%, 77.15 \%, 84.17 \%$, and $83.93 \%$, respectively. The DSTR exhibited good performance compared with the traditional activated sludge (AS) reactor. The resistance to impact load of the DSTR was superior to that of the AS reactor during surface load experiments. During the 120 days of operation, no sludge bulking was observed. The DSTR effluent $\mathrm{NH}_{4}{ }^{+}-\mathrm{N}$ and TCOD levels were a little higher than those for the AS reactor, but the disparity was not major.

\section{Introduction}

The rate of sewage treatment in China's rural areas is low, and large amounts of untreated sewage are discharged directly into lakes and rivers [1]. Many small communities in rural areas lack domestic wastewater treatment facilities [2]. This untreated sewage reduces the surface water quality. For example, the deterioration of water quality in Lake Taihu in China is caused by pollution from domestic wastewater produced in rural areas [3]. In addition, the discharge of untreated sewage would lead to the rise of the organic or inorganic substances in the aquatic environment $[4,5]$ and then increases the chemical oxygen demand (COD) of the receiving water. Large amount of organics discharge would induce to a vast reproduction of bacteria and then the river would lose its self-cleaning capacity. And the nutrient in the sewage such as ammonia can lead to the eutrophication of river. The poor water quality is detrimental to human health because sewage contains large amounts of organic and hazardous chemicals [6]. Therefore, the treatment of sewage in rural areas has recently received more attention in China and needs to be urgently addressed.

The centralised wastewater treatment plants used in municipal areas are not suitable for use in rural areas because of high construction, maintenance, and management costs [7]. Therefore, decentralised sewage treatment processes with high treatment efficiency, low investment costs, and easy operation and management are in urgent demand for rural domestic sewage treatment $[8,9]$.

Several decentralised sewage treatment processes have been applied to sewage treatment in rural areas. These technologies (and their disadvantages) include anaerobic processes (ineffective ammonia nitrogen removal), constructed wetlands (large site area), oxidation ponds (low treatment efficiency), soil treatment systems (low treatment efficiency), and membrane treatment (high investment and operating costs). These technologies have not been widely applied in rural areas because of their shortcomings. In terms of effluent 
quality, the aerobic process is better than the aforementioned treatment processes.

Among existing aerobic processes, the activated sludge (AS) process is most commonly used for treating domestic wastewater $[10,11]$ as it provides good and stable effluent quality. Aeration allows organic contaminants to be degraded completely by microorganisms into carbon dioxide and water. However, the AS process requires strict operation and management $[12,13]$. The aeration tank can deteriorate, if not maintained by professional technicians. In addition, a secondary settling tank is needed to achieve sludge separation, which increases the site area. Another drawback is the requirement of a recirculation system to keep biomass in the aeration pond; this requirement increases the energy consumption of the system. The complicated structure and difficult management of AS technology have restricted its application for decentralised sewage treatment in rural areas.

To solve nonpoint-source pollution problems in China, a treatment process with a simple structure, low operating costs, and easy management that matches the aerobic process in terms of effluent quality needs to be developed. To achieve this, we designed an integrated device named the decentralised sewage treatment reactor (DSTR). The DSTR consists of a sludge separation device and an aeration tank. The sludge separation device has been granted patent rights by the State Intellectual Property Office of the People's Republic of China (patent number 201120250513.X). By combining sludge separation with an aeration tank, the site area is reduced and a sludge recirculation system is not needed, thereby decreasing the operating costs compared with AS reactors. After startup, DSTRs rarely need operational or management input. To evaluate the feasibility of DSTRs in terms of engineering application, their performance was studied and compared with that of an AS reactor consisting of an aeration tank and a secondary settling tank. The prospects for applying DSTRs in the decentralised treatment of sewage in rural areas are discussed.

\section{Materials and Methods}

2.1. Experimental Apparatus. A set of DSTRs, as illustrated in Figure 1, was used in this study. The main reactor compartments were an influent plastic tank $(200 \mathrm{~L})$, and an aeration tank (length $1 \mathrm{~m}$, width $0.65 \mathrm{~m}$, height $1 \mathrm{~m}$ ), and an integrated slurry separating device (inner cylinder diameter $0.14 \mathrm{~m}$, height $0.27 \mathrm{~m}$, external cylinder diameter $0.27 \mathrm{~m}$, height $0.5 \mathrm{~m})$. The slurry separating device was fastened by four support pillars in the centre of aeration tank. The distance between the slurry separation device and the bottom of aeration tank was $0.4 \mathrm{~m}$. The sewage was pumped by a centrifugal pump (LangHe Company, Shanghai, China) into the influent plastic tank. Then a peristaltic pump (Lange Company, Baoding, China) was used to control the flow rate of influent and effluent. Two aeration pumps were used to oxygenate the contents of the reactor, and the air was supplied via several aerators. For comparison, an AS reactor was used; this reactor consisted of an aeration tank (cylinder diameter $0.3 \mathrm{~m}$, height $0.8 \mathrm{~m}$ ) and a secondary settling tank $(7.6 \mathrm{~L}$ effective volume).

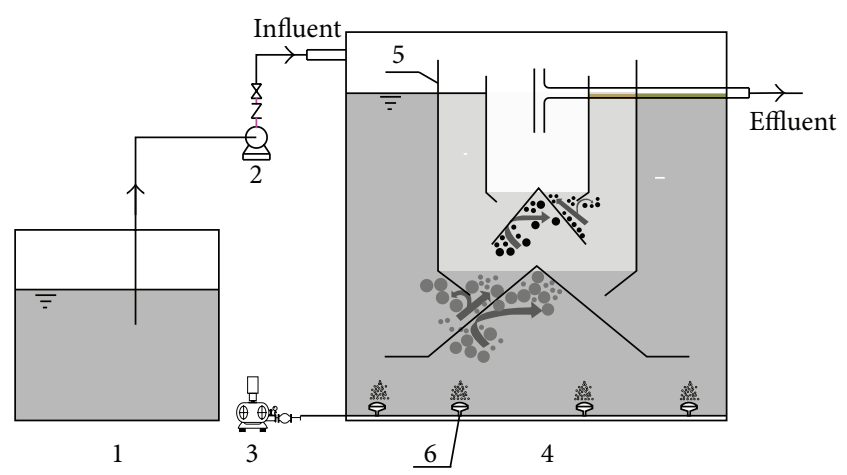

FIGURE 1: Experimental setup of the decentralised sewage treatment reactor (DSTR): 1, influent plastic tank; 2, peristaltic pump; 3, aeration pump; 4, DSTR reactor; 5 , sludge sedimentation device; 6 , aerator.

2.2. Experimental Setup and Operating Conditions. The seed sludge was collected from Qige wastewater treatment plant (Hangzhou, China) and was incubated and acclimated in sewage before the experiments. The total suspended solids (SS) and volatile suspended solids of the sludge were $8.62 \mathrm{~g} / \mathrm{L}$ and $4.38 \mathrm{~g} / \mathrm{L}$, respectively. The $\mathrm{pH}$ was maintained at 6.9-7.9 in the reactor. The sewage had a COD of $179-514 \mathrm{mg} / \mathrm{L}$, an SS level of 40-535 mg/L, a turbidity of 61-370 NTU, and $\mathrm{NH}_{4}{ }^{+}-\mathrm{N}$ levels of $21-42 \mathrm{mg} / \mathrm{L}$.

The experiments were conducted in two phases. During the first phase, the surface loading of the settling zone was increased from 0.1 to $2.5 \mathrm{~m}^{3} /\left(\mathrm{m}^{2} \cdot \mathrm{h}\right)$ to investigate the performances of the DSTR and the AS reactor. As an integrated slurry separating device was used as settling tank in DSTR, the surface loading was calculated on the basis of its surface area. During the second phase, the hydraulic retention time was maintained at $10 \pm 2 \mathrm{~h}$, and the long-term performances of the two reactors were investigated. The concentration of dissolved oxygen (DO) was maintained at $1.3 \pm 0.2 \mathrm{mg} / \mathrm{L}$ throughout the experiments.

2.3. Analytical Method. $\mathrm{NH}_{4}{ }^{+}-\mathrm{N}$, mixed liquor suspended solids (MLSS), mixed liquor volatile suspended solids, and turbidity were measured according to standard methods [14]. COD was measured using a DR2800 spectrophotometer (HACH Company, Loveland, CO, USA). DO was measured by a DO meter (INESA Scientific Instrument Company, Shanghai, China) and $\mathrm{pH}$ was measured by a $\mathrm{pH}$ meter (Mettler Toledo, Greifensee, Switzerland).

\section{Results and Discussion}

\subsection{Sludge Settleability}

3.1.1. Sludge Settleability at Different Surface Loads. The effect of surface load on the sludge settleability of AS and DSTR reactors is shown in Figure 2. For low surface loads, both reactors gave a good performance in terms of sludge settleability; SS in effluent levels lower than $40 \mathrm{mg} / \mathrm{L}$ were observed. For surface loads higher than $1.5 \mathrm{~m}^{3} /\left(\mathrm{m}^{2} \cdot \mathrm{h}\right)$, AS and DSTR reactors exhibited different properties. SS in effluent 


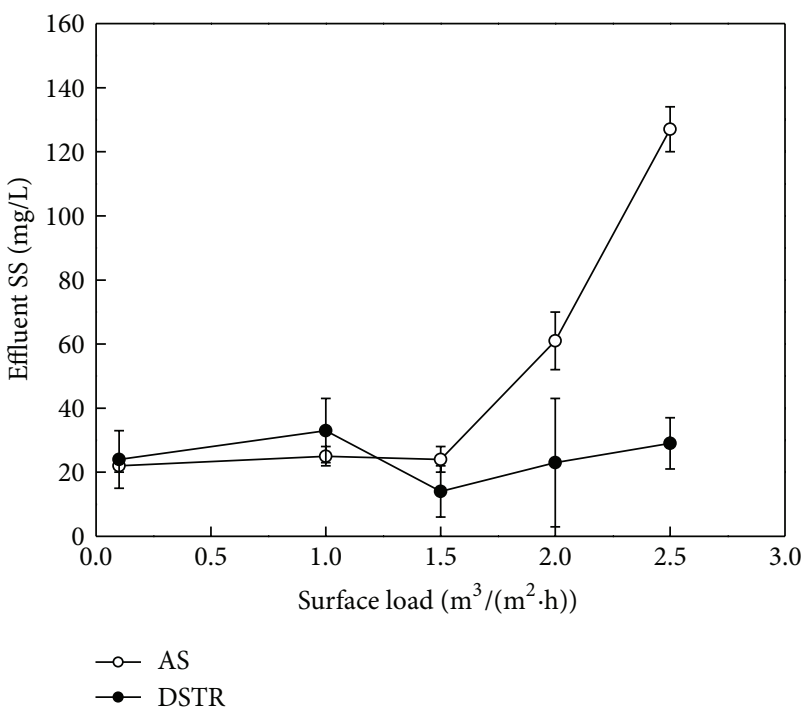

FIGURE 2: Effluent SS levels of the two reactor types under different surface loads. Surface load was calculated based on the area of the sludge separation tank.

levels of the AS reactor increased as the surface load rose, whereas the DSTR maintained good sludge settleability. For surface loads higher than $2 \mathrm{~m}^{3} /\left(\mathrm{m}^{2} \cdot \mathrm{h}\right)$, the settling pond of the AS reactor could no longer function effectively and could not achieve the third grade criteria specified in the Discharge Standard of Pollutants for Municipal Wastewater Treatment Plants of China (GB 18918-2002).

Secondary settling is the final step of the activated sludge-based biological waste water treatment. The main sludge separation mechanism of the AS reactor is natural sedimentation [15]. During the sedimentation process, three zones such as sediment zone, surface zone, and supernatant zone can be observed [16]. The formation of large settleable sludge flocs plays an important role in slurry separation [17]. Some sludge flocs were broken up as a result of hydraulic shock as the surface load rose. Then the area of surface zone might be magnified and resulted in a poor effluent quality in AS reactor. In addition to natural sedimentation, good sludge separation contributes to DSTR performance because of its physical structure. In the present experiments, the form of the effluent was not specified, and this fact might influence the effluent SS concentration. Further study is required in which the optimised effluent form, such as that provided by an overflow weir, is used.

3.1.2. Long-Term Settleability Performance of DSTR. Besides surface loads, the long-term operation performance also is very important for sewage treatment technology in rural areas. The long-term settleability performance of DSTR is shown in Figure 3. The average SS concentration and turbidity in effluent were $36 \mathrm{mg} / \mathrm{L}$ and $29 \mathrm{NTU}$, respectively. A minimum SS concentration of $5 \mathrm{mg} / \mathrm{L}$ was achieved during the experiment. The DSTR exhibited stable SS removal efficiency. Turbidity is a sensitive index for water treatment processes. In this study there was no sludge discharging, and

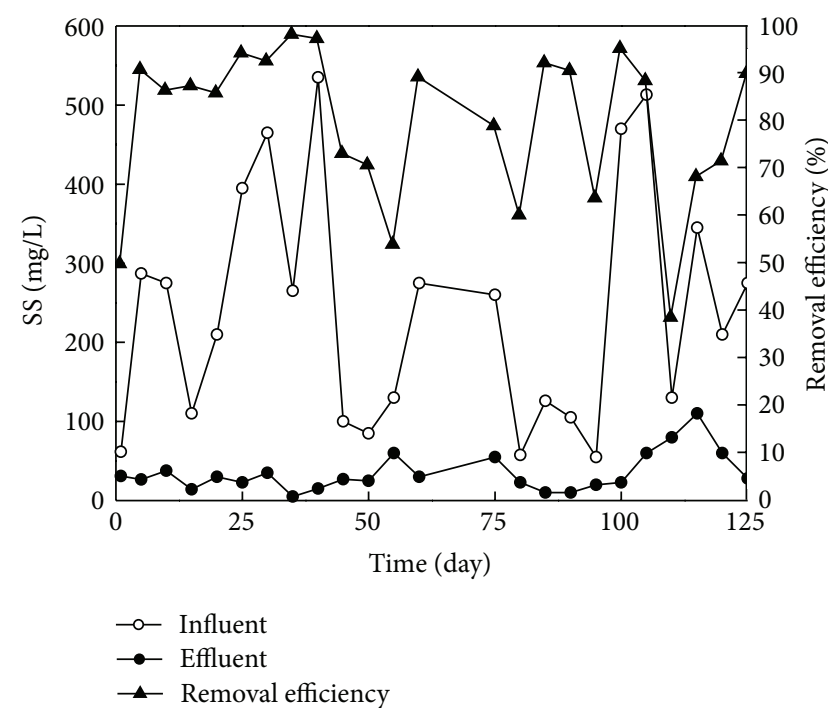

(a)

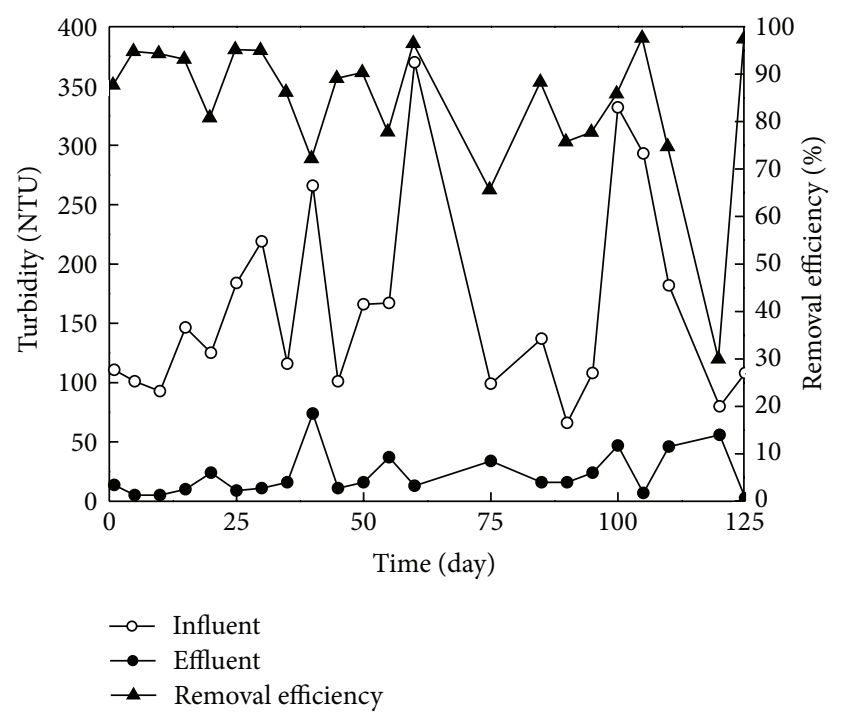

(b)

FIGURE 3: DSTR: (a) SS removal and (b) turbidity removal.

a portion of sludge appeared to undergo autolysis and this might have affected the effluent turbidity.

Sludge settleability is the crucial factor that influences the effluent SS concentration. Activated sludge flocs are aggregates of suspended solids containing different groups of microorganisms and organic and inorganic particles embedded in a polymeric network of extracellular polymeric substrates [18-21]. Sludge settleability can be expressed in a variety of ways, most commonly as some version of the sludge volume index (SVI). The sludge characteristics during the experimental period are shown in Figure 4. The concentration of AS in the DSTR increased from 1.5 to $3.9 \mathrm{~g} / \mathrm{L}$ with no sludge discharge. In contrast, SVI was always below $60 \mathrm{~mL} / \mathrm{g}$ and no sludge bulking phenomena were observed, indicating that the DSTR exhibited good long-term sludge settleability. In general, sludge bulking tends to take place 


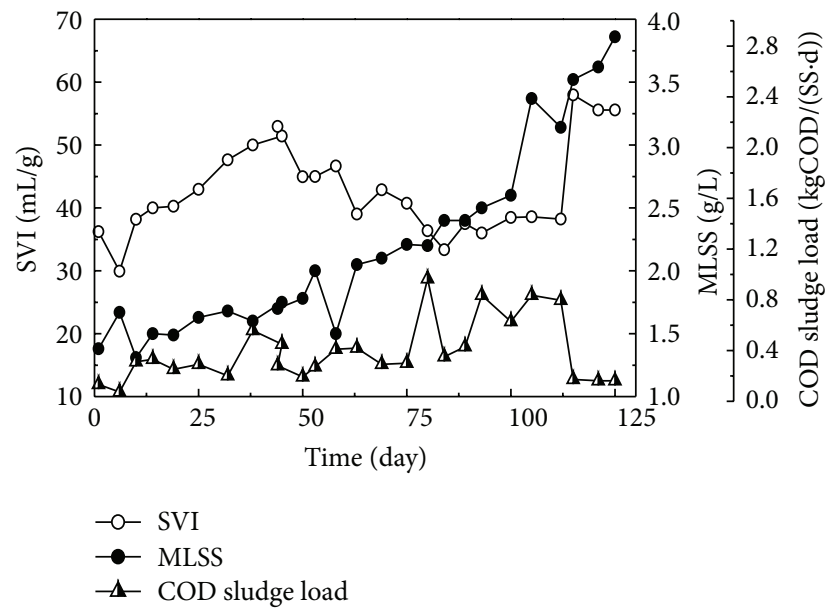

FIGURE 4: Sludge concentration, SVI, and COD sludge load in the DSTR.

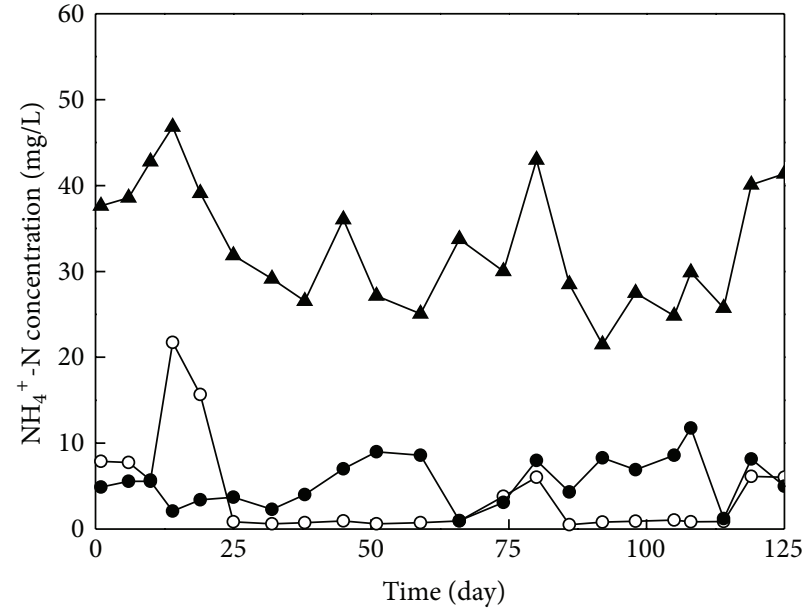

(a)

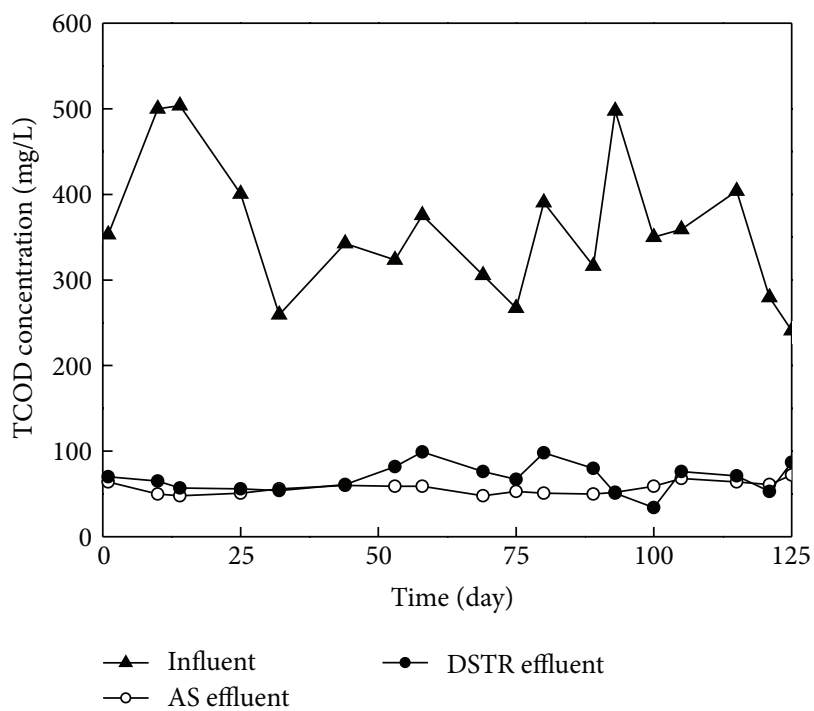

(c)

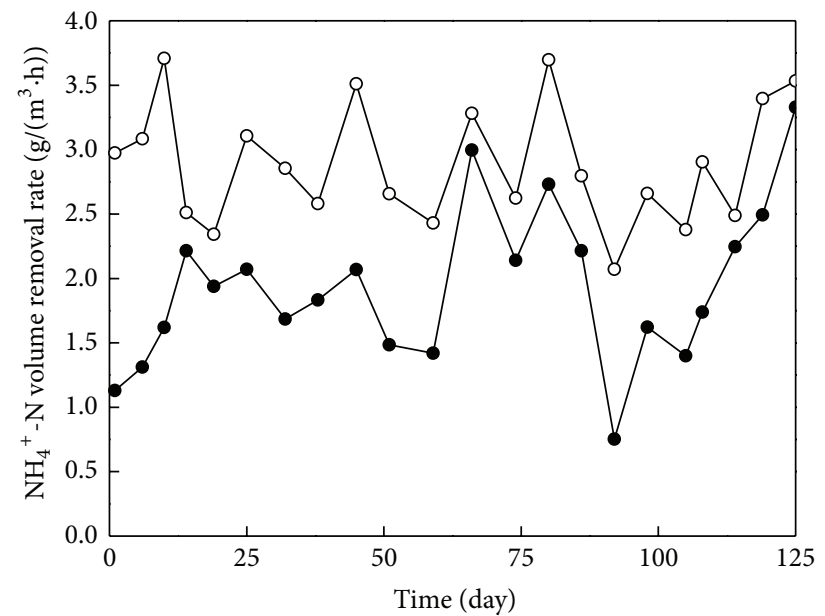

(b)

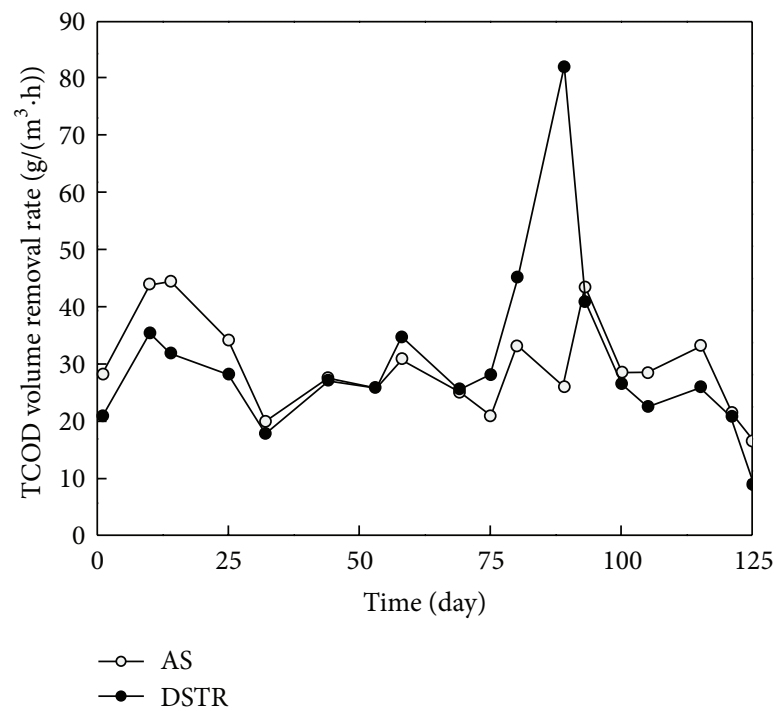

(d)

FIgURE 5: TCOD and $\mathrm{NH}_{4}{ }^{+}-\mathrm{N}$ removal in DSTR and AS reactors. (a) $\mathrm{NH}_{4}{ }^{+}-\mathrm{N}$ removal; (b) $\mathrm{NH}_{4}{ }^{+}-\mathrm{N}$ volume removal efficiency; (c) TCOD removal; (d) TCOD volume removal efficiency. 
when the sludge load is higher than $1.8 \mathrm{kgCOD} /(\mathrm{kg}$ MLSS. $\mathrm{d}$ ) or between 0.6 and $1.3 \mathrm{kgCOD} /(\mathrm{kg}$ MLSS.d) [15]. It can be deduced from Figure 4 that the average COD sludge load was $0.36 \mathrm{kgCOD} /(\mathrm{kg}$ MLSS.d), which is a low value. Then a good settleability performance of sludge in DSTR was achieved. After 125 days of operation, the concentration of sludge in DSTR increased significantly. The sludge yield rate of $19.75 \mathrm{~g} \mathrm{MLSS} /\left(\mathrm{m}^{3} \cdot \mathrm{d}\right)$ was deduced in this study. To keep the sludge concentration between 2 and $3.5 \mathrm{~g} / \mathrm{L}$, excess sludge needed to be pumped out every 75 days. This periodic sludge discharge strategy is feasible for management in rural areas.

3.2. $\mathrm{NH}_{4}{ }^{+}-\mathrm{N}$ Removal. Rural domestic sewage fluctuates in quality and quantity, and so a steady effluent quality is needed to evaluate the performance of treatment facilities. The effect of the DSTR on $\mathrm{NH}_{4}{ }^{+}-\mathrm{N}$ removal is shown in Figure 5(a). The $\mathrm{NH}_{4}{ }^{+}-\mathrm{N}$ concentration of effluent from the DSTR was slightly higher than that of the AS reactor, although the difference was not great: the average $\mathrm{NH}_{4}{ }^{+}-\mathrm{N}$ concentration of DSTR effluent was $5.56 \mathrm{mg} / \mathrm{L}$, compared with $4.14 \mathrm{mg} / \mathrm{L}$ for AS. It was deduced that a good nitrification process was taking place in the DSTR.

Figure 5(b) shows that the $\mathrm{NH}_{4}{ }^{+}-\mathrm{N}$ volume removal efficiencies of the two reactor types varied significantly during the experiment. This probably resulted from unstable influent quality because of the absence of a regulating tank. An appropriately sized regulating tank could be included to improve the treatment effectiveness with respect to $\mathrm{NH}_{4}{ }^{+}-\mathrm{N}$. The volume removal efficiency of the AS reactor was superior to that of the DSTR because the effective volume was different; however, the effluent $\mathrm{NH}_{4}{ }^{+}-\mathrm{N}$ concentrations were similar.

3.3. Organic Matter Removal. Despite variation of the influent quality, Figure 5(c) shows that the effluent total chemical oxygen demand (TCOD) was less than $100 \mathrm{mg} / \mathrm{L}$ after DSTR treatment. The average TCOD removal efficiency was about $76 \%$ for the DSTR, which nearly matches the organic matter removal in the AS reactor. The composition of sewage was complex. Heterotrophic organisms played a major role in TCOD removal. Most organic matter is dissimilated by heterotrophic bacteria in AS systems. After some time, a thin biofilm layer formed as sewage flowed through the surface of the reactor; this biofilm also contributed to TCOD removal. Dignac et al. [22] found that although the organic matter concentration decreased during biological treatment, residual substrates still existed in the effluent after the biological process. These organic matters in the treated water could originate either from products released by bacteria or from nondegraded products. After AS system and DSTR treatment, refractory compounds exist and the TCOD in effluent was measured. Figure 5(d) shows that the TCOD volume removal efficiencies using DSTR and AS were similar.

\section{Conclusion}

After 120 days of continuous running, the DSTR performed well in terms of sludge settleability and contaminant removal. The resistance to impact load of the DSTR was superior to that of the AS reactor. During long-term operation, no sludge bulking phenomena were observed; this fact indirectly signifies good sludge settleability. Although effluent SS levels were steady throughout the experiment, an effluent optimisation stage such as an overflow weir could be added to achieve improved SS removal. The average effluent $\mathrm{NH}_{4}{ }^{+}-\mathrm{N}$ and TCOD concentrations of the DSTR were $5.56 \mathrm{mg} / \mathrm{L}$ and $68 \mathrm{mg} / \mathrm{L}$, respectively, despite variation of influent quality. Our findings suggest that the DSTR is suitable for treating domestic sewage in rural areas.

\section{Conflict of Interests}

All the authors have agreed to submit the paper to this journal and they have no financial or any other conflict of interests in this work.

\section{Acknowledgments}

This work was financially supported by the National Natural Science Foundation of China (50908209) and Key Technology Research and Development Program of Science and Technology Department in Zhejiang province (2010C13001).

\section{References}

[1] L. Xu, H. You, J. Li et al., "Analysis on affected factors of treatment efficiency of rural sewage removal with constructed wetland," Procedia Environmental Sciences, vol. 10, pp. 23142319, 2011.

[2] F. Ye and Y. Li, "Enhancement of nitrogen removal in towery hybrid constructed wetland to treat domestic wastewater for small rural communities," Ecological Engineering, vol. 35, no. 7, pp. 1043-1050, 2009.

[3] S. Li, H. Li, X. Liang, Y. Chen, Z. Cao, and Z. Xu, "Rural wastewater irrigation and nitrogen removal by the paddy wetland system in the Tai Lake region of China," Journal of Soils and Sediments, vol. 9, no. 5, pp. 433-442, 2009.

[4] A. Katsoyiannis and C. Samara, "Ecotoxicological evaluation of the wastewater treatment process of the sewage treatment plant of Thessaloniki, Greece," Journal of Hazardous Materials, vol. 141, no. 3, pp. 614-621, 2007.

[5] M. Karvelas, A. Katsoyiannis, and C. Samara, "Occurrence and fate of heavy metals in the wastewater treatment process," Chemosphere, vol. 53, no. 10, pp. 1201-1210, 2003.

[6] R. K. Sinha, G. Bharambe, and U. Chaudhari, "Sewage treatment by vermifiltration with synchronous treatment of sludge by earthworms: a low-cost sustainable technology over conventional systems with potential for decentralization," Environmentalist, vol. 28, no. 4, pp. 409-420, 2008.

[7] L. Wang, F. Guo, Z. Zheng, X. Luo, and J. Zhang, "Enhancement of rural domestic sewage treatment performance, and assessment of microbial community diversity and structure using tower vermifiltration," Bioresource Technology, vol. 102, no. 20, pp. 9462-9470, 2011.

[8] Y.-S. Li, Y.-Q. Xiao, J.-P. Qiu, Y.-Q. Dai, and P. Robin, “Continuous village sewage treatment by vermifiltration and activated sludge process," Water Science and Technology, vol. 60, no. 11, pp. 3001-3010, 2009.

[9] Q. Zhou, S. L. He, X. J. He et al., "Nutrients removal mechanisms in high rate algal pond treating rural domestic sewage in East 
China," Water Science and Technology: Water Supply, vol. 6, no. 6, pp. 43-50, 2006.

[10] U. Sarkar, D. Dasgupta, T. Bhattacharya, S. Pal, and T. Chakroborty, "Dynamic simulation of activated sludge based wastewater treatment processes: case studies with Titagarh Sewage Treatment Plant, India," Desalination, vol. 252, no. 1-3, pp. 120126, 2010.

[11] A. J. Schuler and D. Jassby, "Filament content threshold for activated sludge bulking: artifact or reality?" Water Research, vol. 41, no. 19, pp. 4349-4356, 2007.

[12] F. A. El-Gohary, S. I. Abou-Elela, S. El-Hawary, S. A. Shehata, H. M. El-Kamah, and H. Ibrahim, "Evaluation of wastewater treatment technologies for rural Egypt," International Journal of Environmental Studies, vol. 54, no. 1, pp. 35-55, 1998.

[13] T. Sabry, "Evaluation of decentralized treatment of sewage employing Upflow Septic Tank/Baffled Reactor (USBR) in developing countries," Journal of Hazardous Materials, vol. 174, no. 1-3, pp. 500-505, 2010.

[14] APHA, AWWA, WEF, Standard Methods for the Examination of Water and Wastewater, American Public Health Association, Washington, DC, USA, 20th edition, 1998.

[15] M. Patziger, H. Kainz, M. Hunze, and J. Józsa, "Influence of secondary settling tank performance on suspended solids mass balance in activated sludge systems," Water Research, vol. 46, no. 7, pp. 2415-2424, 2012.

[16] C. P. Chu, D. J. Lee, and J. H. Tay, "Gravitational sedimentation of flocculated waste activated sludge," Water Research, vol. 37, no. 1, pp. 155-163, 2003.

[17] A. C. Chao and T. M. Keinath, "Influence of process loading intensity on sludge clarification and thickening characteristics," Water Research, vol. 13, no. 12, pp. 1213-1223, 1979.

[18] C. A. Biggs and P. A. Lant, "Activated sludge flocculation: online determination of floc size and the effect of shear," Water Research, vol. 34, no. 9, pp. 2542-2550, 2000.

[19] B.-M. Wilén, B. Jin, and P. Lant, “The influence of key chemical constituents in activated sludge on surface and flocculating properties," Water Research, vol. 37, no. 9, pp. 2127-2139, 2003.

[20] B.-M. Wilén, B. Jin, and P. Lant, "Impacts of structural characteristics on activated sludge floc stability," Water Research, vol. 37, no. 15, pp. 3632-3645, 2003.

[21] B. Frølund, R. Palmgren, K. Keiding, and P. H. Nielsen, "Extraction of extracellular polymers from activated sludge using a cation exchange resin," Water Research, vol. 30, no. 8, pp. 1749-1758, 1996.

[22] M.-F. Dignac, P. Ginestet, D. Rybacki, A. Bruchet, V. Urbain, and P. Scribe, "Fate of wastewater organic pollution during activated sludge treatment: nature of residual organic matter," Water Research, vol. 34, no. 17, pp. 4185-4194, 2000. 

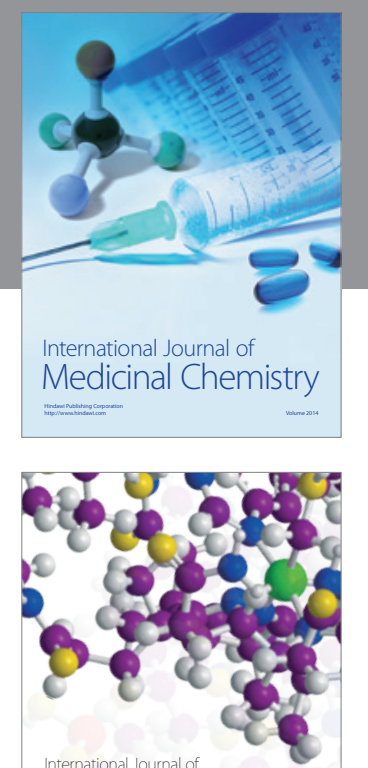

\section{Carbohydrate} Chemistry

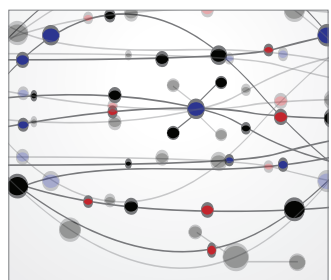

The Scientific World Journal
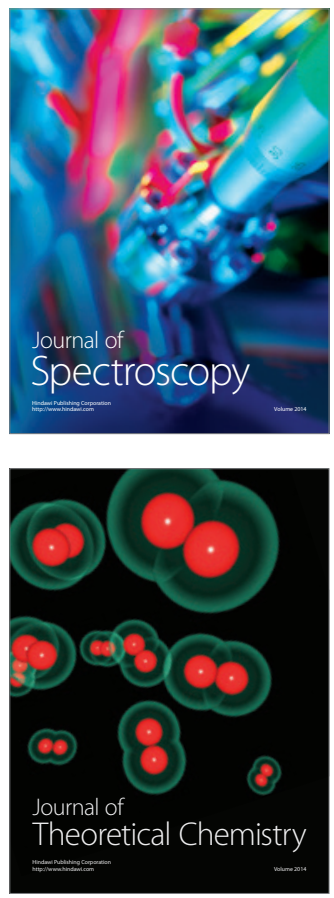
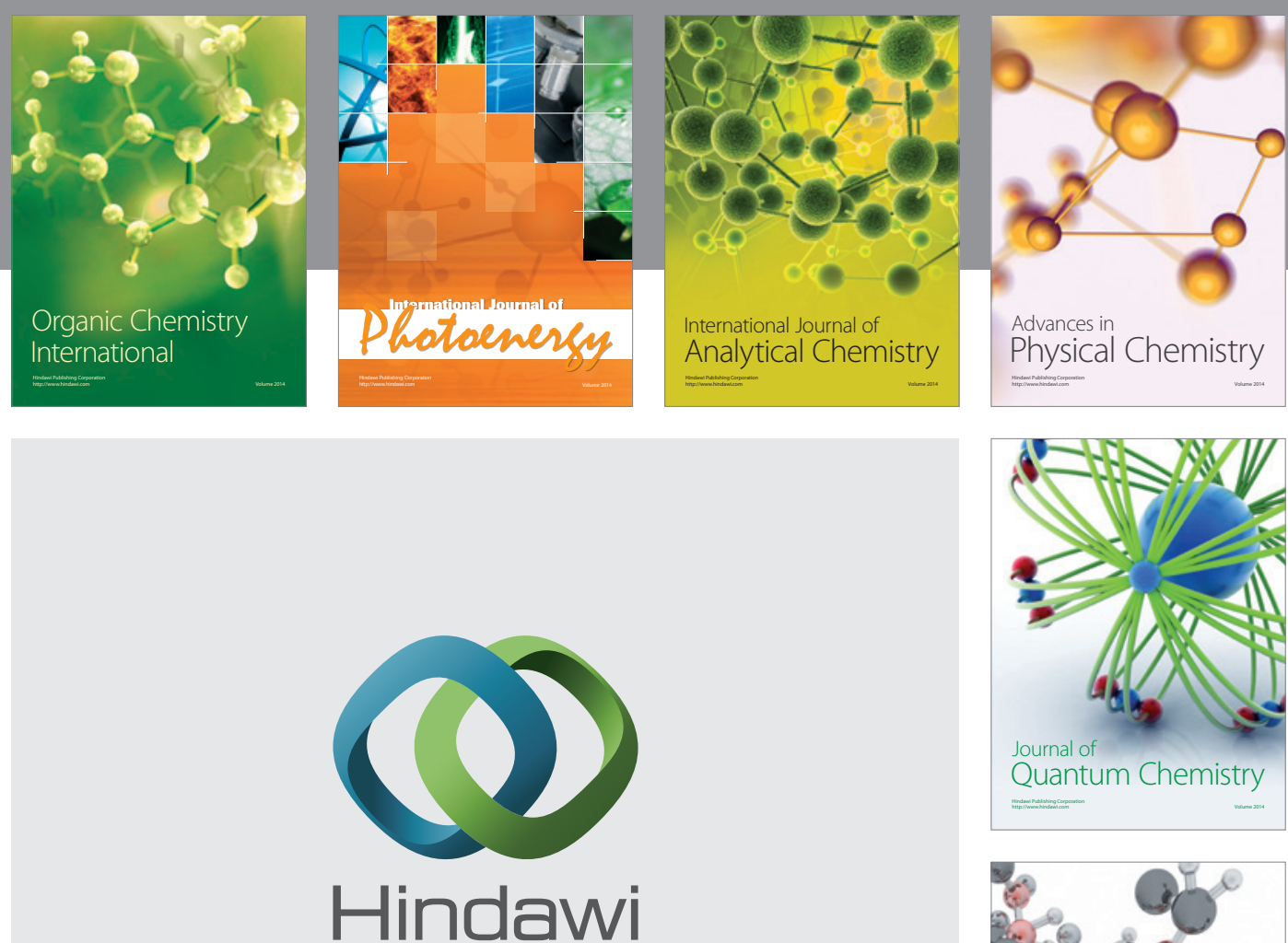

Submit your manuscripts at

http://www.hindawi.com

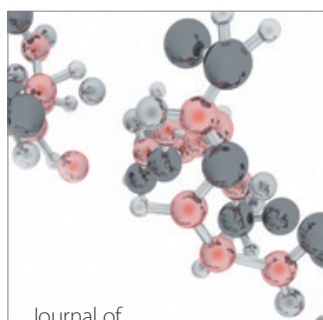

Analytical Methods

in Chemistry

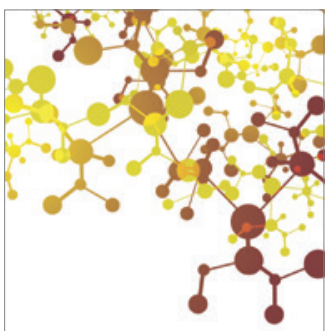

Journal of

Applied Chemistry

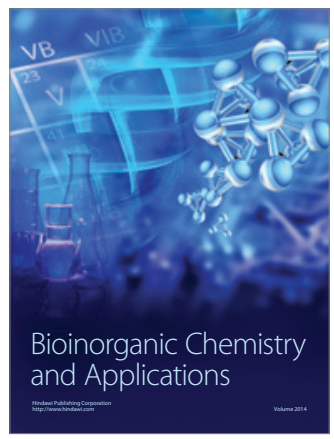

Inorganic Chemistry
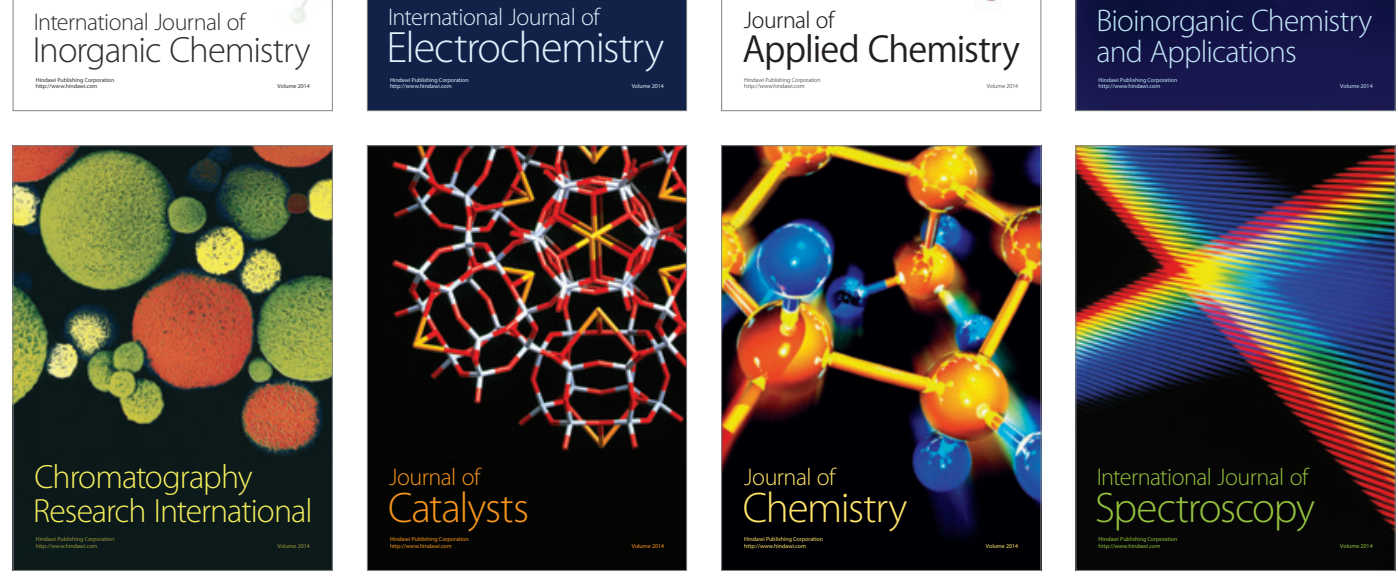